\title{
The Evolution of Southeast Asian Regionalism: Security, Economic Development, and Foreign Power Support for Regional Initiatives, 1947-77*
}

Sue Thompson

Australian National University, Australia

\begin{abstract}
Policy objectives for Southeast Asian regionalism had been evolving since the end of the Second World War. Economic development viewed as essential for establishing peace and stability in Southeast Asia and the links between development and security were evident in the elaboration of the Association of Southeast Asian Nations (ASEAN). Also evident was the second-line support provided by external powers. While ASEAN was a regional initiative that came out of the Bangkok talks to end Confrontation, Western governments had been formulating regional cooperation policies in Southeast Asia decades prior. Economic development viewed as essential for containing communist influence and preventing internal insurgencies in the region. Growth and prosperity would come through regional development programs with external support. This would then expand to some form of collective security led by the Southeast Asian nations themselves. Regionalism viewed as one way of providing economic assistance to newly independent nations without the appearance of foreign interference in regional affairs. Therefore, the evolution of Southeast Asian regionalism was a combined effort of foreign power support for Asian initiatives throughout the economic development with the aim to provide security during the political transformation of the region from the post-war period into the early years of ASEAN and the aftermath of the war in Vietnam.
\end{abstract}

Key words: regionalism, Southeast Asia, economic development, security

- This article was originally presented in The Fifth International Conference on Business, International Relations, and Diplomacy (ICOBIRD 2016) at Bina Nusantara University. 


\section{Introduction}

At the end of the Second World War, early efforts towards Southeast Asian regionalism emerged from Southeast Asian nations seeking to achieve peace and stability, economic development and policies of self-reliance. Western governments too were pursuing their policies on regional cooperation for similar outcomes. For the United States (U.S.) especially, such agreement would provide stability for a grouping of non-communist nations without the appearance of Western support, as well as a multilateral umbrella under which bilateral relationships between the West and Southeast Asian countries would thrive and prosper. These policies have often overlooked when tracing the post-war evolution of Southeast Asian regionalism as the focus of this topic has tended only to highlight the role played by the regional nations themselves. Indeed, officials such as Abu Bakar Lubis, the private secretary to Indonesian Foreign Affairs Minister Adam Malik, have promoted this perception, denying that formal regional cooperation was the result of an American idea or action (Anwar, 1994, pp. 49-57). Additionally, perceptions of the role of regional cooperation have highlighted economic and social issues, rather than any security benefits, missing the importance of regionalism as a vehicle for promoting both economic development and safety policies of regional and external powers.

Western governments initially sought to secure regional peace and cooperation through the United Nations (UN). Washington was interested in collaboration among groups in the UN where there was mutual interest, such as regional cooperation. Australia and New Zealand too saw the benefit of such an arrangement, taking the initiative to seek consultation with the U.S. on the future of the Pacific region at the end of the war. Britain was also supportive of the idea of regional cooperation and looked at developing a policy for its colonial areas. Both the British and the Australians believed that some form of regional cooperation was much preferable to a post-war mandate system (Letter, Evatt to Johnson, 1944). Securing support from the region was crucial for officials who were keen to avoid direct interference in the affairs of governing bodies, and within Asia, some states also backed the idea of closer cooperation, especially those that supported decolonization, but not pro-communist independence movements.

However, regional cooperation could only succeed if Southeast Asian nations themselves agreed that there was a need for closer relations and would work together. This need did come from the common fear of China's domination in the region and concern for economic development, especially once Western interests reduced. The creation of formal regional cooperation came with the establishment of the Association of Southeast Asian Nations (ASEAN), a move that was only possible through regional initiatives from the founding member states. Indeed, the creation of ASEAN attributed to efforts from the countries in the region, especially ASEAN's conception was a direct result of the Malaysian-Indonesian talks that ended Confrontation, the conflict between these two nations. However, Western policies did contribute to the evolution of regional cooperation in Southeast Asia, reflecting the 
combined efforts of foreign power support for Asian initiatives.

\section{Early Initiatives}

On 4 July 1949, Philippine President Quirino made a speech outlining the need for a 'Pacific Union, a real union of peoples around the Pacific on the basis for common counsel and assistance.' Quirino then sent a letter of instructions to General Romulo, Philippine Diplomat and President of the UN General Assembly at the time, outlining his plans for such an organization. Romulo responded and proposed that Korea, the Philippines, Thailand, New Zealand, Australia, India, Burma, Ceylon and Indonesia organize a political and economic union aimed at containing 'Russo-Chinese' Communism, while also denouncing European imperialism. Britain, France, the Netherlands and the U.S. would at first excluded from such an organization. After some form of grouping emerged, an offer of economic cooperation with the U.S. would pursue. Then, if Communism could contain, a joint appeal for American military aid could be considered (Memo, for Butterworth and Fisher, 1949).

The links between economic development and security had been evident from the beginning of the UN and had resulted in the establishment of some agencies such as the Economic and Social Council (ECOSOC) and the International Bank for Reconstruction and Development (IBRD), amongst others. In early 1947, ECOSOC created regional commissions to encourage development, and one of these bodies was the UN Economic Commission for Asia and the Far East (ECAFE), which was established on 19 March 1947. The membership of ECAFE included both Asian countries and non-regional members such as France, the Netherlands, the Soviet Union, Britain, and the U.S. As the Cold War intensified, the Australian Government particularly, promoted the commission as a forum for non-communist governments and capitalist development (Mitcham, 2012, p. $191 \& 1930)$.

However, Washington and several other countries were cautious about Philippine overtures towards the development of a Pacific Union. When General Romulo tried to undertake preliminary discussions on the idea with various diplomatic representations at the $\mathrm{UN}$, several nations indicated that American policy would largely influence their position. Following this, Romulo attempted to secure a commitment from Washington to support the participation in a Southeast Asian meeting. The response from the State Department was that while the U.S. would be sympathetic to the principle of a Southeast Asian association, the success of any such group would have to be generated spontaneously within the area (Memo, Secretary of State and Butterworth, 1950).

Nevertheless, the U.S. continued to promote the idea of Asian regionalism to counter anti-Western forces. This idea reflected in support for the development of the Mekong River Basin. Post-war interest in developing the area came out of French-Thai negotiations to settle a territorial dispute. In 1950, former Office of Strategic Service Director William Donovan recommended that the administration support the development of the Mekong Basin as a longrange project to secure cooperation between Burma, Cambodia, Laos, Thailand, and Vietnam. This concept presented to ECAFE, and in 1957, the Committee for the 
Coordination of Investigations of the Lower Mekong Basin established. In 1958, Washington provided US\$2 million to help finance the collection of primary data in the area. The State Department viewed the Mekong Committee as having enormous potential for the political and economic future of the region, 'in determining whether Southeast Asia remains free or comes under the control of the Sino-Soviet Bloc' (Memo, Landon to Rostow, 1961).

By the early 1960s, there were some regional organizations in existence, but only a few with solely Asian membership. The Association of Southeast Asia (ASA) - an economic and cultural organization that included Malaya, the Philippines, and Thailand - was one such organization. It founded in 1961, yet its functions limited, especially when the Philippines refused to recognize the newly created Federation of Malaysia, because of a Philippine claim to the British Borneo territory of Sabah. Another organization was Maphilindo, for Malaya, the Philippines, and Indonesia. Its purpose was to unite the Malay world, and arose out of the Manila Agreement, a report by the Foreign Ministers of those countries, accepted and augmented by the three heads of government in meetings in Manila in July and August 1963. They agreed that foreign bases should not undermine their independence, although Maphilindo came to nothing because of the outbreak of Confrontation, and Manila's claim to Sabah (Minute, Mare to Mr. Samuel, 23 January 1967).

\section{American Initiatives}

Under President Johnson, the Department of State continued to pursue regional cooperation as a policy objective, supporting two main goals in Southeast Asia as interdependent: security and social and economic development (Administrative History of the Department of State, 19631969). In early 1965, State Department advisers suggested to Under-Secretary of State George Ball, that some Asian development defense agency, or organization, might be initiated to replace existing groups. Ball agreed to consider such an approach (Conversation between Ball and Talbot, 1965). However, many in Washington were wary that this policy would portray as American interference. In April 1965, Chester L. Cooper, a staff member of the National Security Council (NSC), suggested that Washington should present to UN Secretary General, U Thant, the idea of forming a new regional institution called, The Southeast Asia Development Association. It would be a coordinating and consultative organization with permanent staff and an executive agent for the management of multi-national capital projects, and the concept must appear to be an Asian initiative and be Asian (Talking Points for Bundy from Cooper).

Many officials felt that regional cooperation was to be an Asian idea, privately Washington attributed main part of its implementation to American money. Johnson's Secretary of State, Dean Rusk, claimed that one important step towards regional cooperation was the provision of US\$1 billion for economic development in Asia, as outlined in a speech delivered by President Johnson at Johns Hopkins University. Another important step was directing this US $\$ 1$ billion towards the establishment of the Asia Development Bank (ADB) and other regional programs (Rusk to Rev. Dusen, 1965). 
Until Confrontation ended, regional security cooperation was unfeasible. However, economic development could be a means to end that dispute, and improve relations between Indonesia and other Southeast Asian countries, especially Malaysia and Singapore. When Washington commented favorably on Maphilindo as an organization that might provide the means of promoting regional cooperation and of finding a solution to Confrontation, Singapore Prime Minister Lee Kuan Yew, expressed his concern that the U.S. was supporting the resurrection of Maphilindo. Department of State officials told Lee that Maphilindo was an Asian and not an American initiative and that the State Department did not want any plans for trade and security cooperation perceived as American interference (Washington to Singapore, 1965).

By mid-1966, some regional and subregional cooperative initiative had evolved such as the Asian Pacific Council (ASPAC) an economic and cultural alliance made up of non-communist countries within the region, the ADB and the ASA. State Department officials believed these bodies were promising for future progress in regional and sub-regional cooperation that would, in turn, led to collective efforts at solving economic, social and security problems in Asia (Memo for Rostow from Jorden, 1966). Donald D. Ropa of the NSC Staff stressed to National Security Adviser, Walt Rostow in April 1966 that American security interests in the Pacific basin would be dependent on more regional cooperation for economic development and political cooperation for mutual security concerns. The ASA or Maphilindo might be able to evolve as a wider cooperative group, depending on Indonesia's participation. Consideration would then have to be taken as to the form and substance of such a group, what its relationship would be with other regional organizations and in what direction would American diplomatic initiatives follow in furthering the idea (Memo from Ropa to Rostow, 1966).

Continuing American interest in Asian economic development and regional security cooperation continued as Johnson made a trip to the region in OctoberNovember 1966. There he met with the heads of six nations - Australia, New Zealand, the Philippines, the Republic of Korea, South Vietnam and Thailand - in Manila on October 24-25. This meeting closed with a declaration of Peace and Progress in Asia and the Pacific and all seven heads of government declared strong support for the principle of regional cooperation (Administrative History of the Department of State, 1963-1969).

\section{British Support and the End of Confrontation}

London also supported regional cooperation for Southeast Asia, especially considering Britain's military commitments to the region. In early 1964, the British Embassy in Washington delivered an Aide Memoire to the White House posting that Western withdrawal from Vietnam or Malaysia was inevitable and if there was any chance of stabilizing an independent Southeast Asia without the presence of Western forces, regional cooperation was an undeniable attraction. This withdrawal was an ideal situation in the long-term, but it was not possible in the short-term, especially due to the leftist chaos of Indonesia (British Embassy in Washington Aide Memoire, 
1964). However, the British did not present any ideas on how to progress this issue. In May 1965, Rusk suggested to his British counterpart, Michael Stewart, that Washington and London should do more to encourage Southeast Asian countries to cooperate. With the aim of reducing British or American military involvement in the region, suggesting the establishment of an organization around Malaysia, the Philippines, and Thailand (Record of discussion, Rusk, and Stewart, 1965).

Some Southeast Asian states supported the departure of Western military bases from the region, but not all. Indonesian leader, General Suharto reportedly said in February 1966 that the defense of Southeast Asia was a matter for the countries in the area and that the British military base in Singapore was a target for China's expansionism. The Malaysian and Singapore governments, on the other hand, wanted the base to stay (Kuala Lumpur to Ottawa, 1966). Nevertheless, cooperation between the Southeast Asian nations was required. London was quite keen on the establishment of an organization like the defunct Maphilindo, with the addition of Singapore. However, the Malaysians were less sure of resurrecting this organization. Kuala Lumpur's preference was for the ASA, which would include Thailand. Regardless of the form such an association would take, London's position was to support any new organization that might emerge from the Bangkok talks between Malaysia and Indonesia on ending Confrontation (Memo, Pritchard to Lord Beswick, 1966). Britain was uncertain whether a regional organization would discuss at these meetings; however, it instructed its missions in the region to stress its approval for some form of regional cooperation in Southeast Asia that would be worked out by the participating countries (London to certain missions, 1966). Then London could plan for the withdrawal of its forces from Singapore. While Washington wanted the British military bases to stay for at least the immediate future, the hope of some U.S. officials was that out of the regional initiatives implemented in the early 1960s. The initiatives would uniquely be Asian mutual security arrangements, buttressed by American power presence, which will compensate for ultimate British withdrawal (Ropa to Rostow, 1966).

\section{Formal Initiatives and the Creation of ASEAN}

It informally agreed at the Bangkok talks that Indonesia should join an ASA-type body that would give a new name (Kuala Lumpur to London, 1966). Indonesia was keen to see that foreign forces withdraw from the region and new Indonesian President Suharto wanted closer ties with his neighbors to help stem the spread of China's influence in the area (Jakarta to Washington, 1966). He told two British Members of Parliament that an Asian community should be responsible for the security of Southeast Asia (Meeting, Jackson MP, Dalyell MP, and General Suharto, 1966). Thai Prime Minister Thanom Kittikachorn and Malaysian Prime Minister Tunku Abdul Rahman said that they were pleased that countries in the region were increasingly aware of the need for regional cooperation, and stressed their determination to make a Southeast Asian association work (Kuala Lumpur to Washington, 1966). Malaya had been the initiator of ASA and was a participant of Maphilindo, and was now, like Malaysia, willing to join a regional organization that 
would include members of Singapore. The Australian High Commission in Kuala Lumpur saw the possibility that a new local organization would make Malaysia less dependent on its non-Asian allies (Kuala Lumpur to Canberra, 1966). Malaysian Finance Minister Tan Siew Sin explained to U.S. officials that the American nuclear umbrella and a Southeast Asian regional organization were the only two alternatives to avoid the spread of communist influence (Kuala Lumpur to Washington, 1966).

The Malaysian Government specifically, agreed with continued Western support in Southeast Asia. During a meeting between Malaysian Deputy Prime Minister Tun Abdul Razak and U.S. Defense Secretary Robert McNamara in Washington, Razak said that from Malaysia's perspective, it was important to have Laos, Burma, Cambodia, and Thailand coordinating policy to keep any pressure from China away from Malaysia's borders. McNamara then emphasized the importance that the U.S. attached to the creation of some form of regional grouping so that American forces could eventually withdraw from the Asian mainland (Washington to Kuala Lumpur, 1966). In Thailand, Thai Foreign Minister Thanat Khoman had told Humphrey, he wanted to gather representatives from noncommunist Asian countries to promote increased regional cooperation. The Japanese Prime Minister, Eisaku Sato, and the South Korean President, Park Chunghee, backed this sentiment (Letter, Vicepresident to Johnson, 1966). However, Thanat did not want overt American support. He told Rusk that he hoped regional development could have America's discreet blessing. When the Secretary of State asked if Bangkok did not want U.S. support to be too obvious, Thanat replied that he was sure Washington would be able to determine where and when it could provide useful assistance (Record of conversation between Rusk and Khoman, 1966).

However, problems arose over whether the organization would involve itself in regional defense. Malik stressed to the American Ambassador in Jakarta in early 1967 that the new regional group would only be an economic, cultural and technical association and that defense matters would not consider; although in time ASEAN would take on a more political role (Jakarta to Canberra, 1967). However, one defense matter that was discusses was the presence of foreign military bases in the region. Indonesia was opposed to such bases and wanted this reflected in the new organization's declaration. This opposition had been an aim of the previous regime in Jakarta and had been part of Sukarno's antiimperialist rhetoric during Confrontation. For the apparent pro-Western Suharto government, the motivations for opposing foreign bases seemed less clear. However, in early 1967, officials told Australian and British representatives that the Indonesian military stood to gain significantly if countries in the region opted out of defense arrangements with non-regional powers and instead organized their defense plans with the participation of Indonesia (NIC 303(74), First Draft, 1974). Although, the Acting Director of Asian Regional Affairs at the State Department, Philip Manhard, also told the Australians that it was difficult to determine how far Malik was interested in ASEAN taking on a security role and whether the Indonesian Army was pushing for this position. Manhard pointed out that 
in a recent speech, Malik had denied that the new regional grouping would have a security role, but had then made contradictory statements, commenting that regional security had discussed amongst the five nations (Washington to Canberra, 1967). Back in May 1967, Malik asked whether proposals for the new regional organization would include a joint military security plan against communist infiltration, he replied that regional cooperation along the lines of economic, cultural and technical partnerships could interpret as a form of defense (Kuala Lumpur to Canberra, 1967).

When ASEAN was inaugurated on 8 August 1967, the State Department regarded the formation of ASEAN as a positive move, despite the indication that member nations would not welcome any form of outside interference, and not just from China. Washington was not overly concerned about the paragraph relating to foreign bases, believing the negotiations had largely avoided contentious political issues (Washington to Canberra, 1967). The Soviets denounced ASEAN, labelling it a new military group and China completely ignored the new organization. ASEAN's declaration stated that the countries in Southeast Asia would cooperate on economic, social and cultural development. The founding countries also declared their commitment to stabilizing and securing the region from external interference (Gill, 1997, pp. 30-33). The declaration added that all foreign bases were temporary and that the countries in the region shared the main responsibility for defending Southeast Asia, although ASEAN was not directly concerned with defense. Of the five founding members, Indonesia was the only country that did not have Western forces inside its territory, and
Jakarta insisted on a statement reflecting the temporary nature of Western bases in the region. For Indonesia, the declaration must refer to the foreign bases, and stipulate that the region was responsible for its defense. However, the other four nations also did not emphasize ASEAN as a security organization (Canberra to all posts, 1967). Indeed, days later, when the Soviet Ambassador to Thailand asked Thanat about the issue of bases, he responded that the military bases stationed in Thailand was Thai and not American and that the U.S. was only needed to use these bases in the face of North Vietnamese aggression (Washington to Canberra, 1967).

The Australian Government, on the other hand, seemed to view the organization as a forum to promote security in the region. A day after ASEAN's inauguration, Australia's Minister for External Affairs, Paul Hasluck, praised the new association and its aims at increasing cooperation amongst the member states. He added that ASEAN not only had committed to support economic growth, social progress and cultural development in the region but to also 'promote regional peace and stability' objectives that had the full support of Canberra (Canberra to certain posts, 1967). Years later, in his memoirs, Lee Kuan Yew wrote that the unspoken objective of ASEAN was to build strength through regional solidarity before a power vacuum was created because of the British military withdrawal from Southeast Asia and a possible American one later (Yew, 2000, p.369).

\section{The Early Years of ASEAN}

However, in the early years of ASEAN, the organization was loosely 
structured, and Singapore was the only member state that gained any great financial benefit. The Singaporeans pushed for issues such as tourism, shipping, fishing and intraregional trade to be considered by the first meeting of the ASEAN standing committee, hoping that these economic projects would lead to closer involvement in regional planning. However, four of the five founding members - Thailand, Malaysia, Indonesia, Philippines - had similar and competed for agricultural economies and economic nationalism was expected to be a major hurdle for the new organization. Singapore was the country best suited economically to a regional arrangement. As a result, the Australian Government's assessment of the benefit of ASEAN was that it would carry more significance in the political rather than the economic sphere (Canberra to all posts, 1967). Indeed, this view was reflected in the outcome to internal tension within the organization through Manila's ongoing claim to Sabah that caused the breakdown of Philippine-Malaysian diplomatic relations in 1968. ASEAN encouraged a resolution of the crisis and Indonesia was given credit for acting as an effective mediator (Talking points for meeting with Malik, by Kissinger, 24 September 1974). However, the approach was essentially one of non-interference in member disputes, reflecting the way ASEAN tackled both external and internal pressures through a philosophy of non-interference and consensus (Tarling, 2006, p. 210).

Debate on the future role of ASEAN emerged at a meeting of foreign ministers in December 1969. The opening statements from some ministers revealed emerging issues on whether the organization would deal solely with economic and cultural cooperation, or try to forge ahead into the security arena. Singaporean Foreign Minister, S. Rajaratnam, stated that his government believed ASEAN should stay solely focused on economic cooperation in Southeast Asia. Whereas Malik referred to Britain's military withdrawal and a prospective American disengagement as cause for the member states to 'induce us to jointly consider policies in our effort to cope with the new emerging situation.' Thanat Khoman also mentioned security concerns, which was reiterated by the Malaysians, stating that there was scope to work out some form of security arrangements and that member countries should take responsibility for their region following any power vacuum left by departing Western forces (Kuala Lumpur to Canberra, 1969).

Fueling these security concerns was the announcement in January 1968 of Britain's intention to withdraw all its military forces from Southeast Asia by 1971 and U.S. President Nixon's statement on the island of Guam in July 1969 that the U.S. expected Asian nations to assume more responsibility for their defense. America would keep all existing treaty commitments, but would not enter any new ones, unless they were vital to the interests of the U.S. In the case of internal subversion in Asia, assistance from Washington would not be in the form of troops, but development aid, military equipment, and training (Record of meeting between Wilson and Nixon, 1969).

Later in the Philippines, Nixon nevertheless continued to stress the importance of economic development as a vehicle for increased stability in Asia. In a statement, the American President reiterated U.S. was backing for the ADB saying that he had asked Congress to appropriate US\$20 
million for the ordinary capital of the ADB and US\$25 million to its special fund for the following fiscal year. He also stressed that the Bank was an Asian institution with its headquarters in Asia and with a requirement that 60 per cent of its capital must come from Asia. While the U.S. and other non-Asian countries could play a role, the leadership of the Bank must always come from Asia (Nixon Statement, 1969). Then, a few weeks later, Secretary of State William Rogers supported Nixon's position in a speech to the media in Canberra. He stressed that American policy in Asia would be to encourage Asian leaders to meet their own internal security needs with material assistance from the U.S. and to encourage 'rapid economic development of the area with emphasis on increasing regional cooperation' (Rogers speech, 1969). Nixon publicly announced in January 1970 his proposal to ask Congress to authorize a contribution of US $\$ 100$ million to the ADB's Special Funds over a three-year period US\$25 million in the first fiscal year, and then US $\$ 35$ million and US\$40 million in the following two fiscal years. He stressed that since the ADB's establishment, the bank had made a major contribution to Asian economic development and that it provided a 'unique capability for acting as a catalyst for regional cooperation' (White House Press Statement, 1970).

However, officials American Embassy in Singapore warned Washington that if Southeast Asian regionalism were to be successful, nations there must be sure that the U.S. would not abandon them (Singapore to Washington, 1969). Kissinger too stressed this position to the American Vice-President in December 1969, before Spiro Agnew's proposed to visit the region. During the visit to Indonesia, Kissinger told Agnew that he should stress that Jakarta's pursuit of regional economic policies and multilateral economic aid approaches justified America's aid program to Indonesia (Memo, Kissinger to Agnew, 1969). Indeed, by the end of 1969, the administration in Washington had noticed that Asian nations were starting to rely less on individual outside aid donors. The Asian begin to rely more on multilateral aid organizations such as the ADB and the International Monetary Fund (IMF), and that the Americans welcomed the creation of other Asian organizations based on Asian initiatives. Therefore, while the U.S. did not want to interfere, it would be willing to assist multilateral and regional organizations where possible (Memo, East Asia and the Pacific, 1969).

\section{The Changing Regional Scene}

Overall, the response of Southeast Asian leaders to Nixon's comments was that they viewed the so-called Nixon Doctrine as a warning signal that the U.S. would eventually disengage from the Asian mainland and regional allies must assume greater responsibility for their security. For some regional nations, the American policy announcement was in step with current aspirations, such as Bangkok's efforts to move towards a more independent foreign policy path and Manila's wish to move beyond the traditional image as an American strategic client (Acharya, 2012, p. 140). The Australian Embassy in Manila reported that the Philippines appeared to be in favor of Southeast Asian nations becoming more selfreliant. Philippine President Marcos's proposal for an Asian forum to 'solve Asian problems' and his foreign secretary's references to Asian security arrangements indicated that Manila acknowledged the 
changing role of future American involvement in Southeast Asia and admitted that the Philippines would become more involved regionally (Manila to Canberra, 1970).

Thanat Khoman told the Australians that he believed China would become a more serious problem after the end of the war in Vietnam and that countries in the region had only two alternatives: either submit to China or unify and develop a front, which the Chinese would have to accept. A pact was not necessary for this purpose, instead of regional cooperation based on mutual understanding and self-interest was all that was needed (Bangkok to Canberra, 1969). However, a year later, the Thai Government seemed to recognize that regional cooperation alone would not provide in the immediate future any prospect of an alternative security backing. This recognition was because of the disparity of power between countries in the region, the internal instability in most Asian nations and Bangkok's reluctance to accept the risks that would be involved in any new mutual security arrangement. Nevertheless, regional cooperation potentially provided an opportunity for Thailand to supplement its security alliance with the U.S. by underpinning political and economic ties with its neighbors (NIC Note 4/70, 1970). This assessment was made a few months after Thailand secured additional financial assistance from Washington. In August 1971, Nixon directed that a US\$45 million special assistance packaged negotiated with Bangkok to strengthen the Thai economy and defense capabilities. The Americans hoped this would accelerate the improvement of Thai armed forces capabilities so that they might be capable of facing any possible contingencies (Memo 126, 1971).

Malaysia's reaction to Nixon's declaration was to support bilateral relationships between countries of the region but without treaty ties or another institutionalization. This policy stemmed from the announcement of not just the Nixon Doctrine, but also the British intention to withdraw militarily. Kuala Lumpur's doubts about the utility of the newly formed FivePower Defence Arrangements (FPDA) between Britain, Australia, New Zealand, Singapore, and Malaysia, as well as limited expectations of Australian and New Zealand assistance (Kuala Lumpur to Canberra, 1970).

Singapore's response to the changed strategic environment was to build its defense forces, but these efforts were not a direct reaction to the so-called doctrine, although Singapore's efforts for closer cooperation in defense matters with Malaysia could have been encouraged by it. However, since the British announcement, Singapore had been building its military due to its geographical proximity to Malaysia and Indonesia (Singapore to Canberra, 1970).

The Indonesians seemed to accept much of what was outlined by Washington and emphasized the need for extensive foreign aid to counter the military weakness of the countries in the region. In fact, the concept of increased economic development to replace a foreign military presence suited the government in Jakarta that was quick to point out that Indonesia lacked the capacity to contribute to the joint defense and military security. Rather its priority was economic development (Jakarta, Kuala Lumpur, Singapore to Canberra, 1970). Nevertheless, 
Indonesia became the beneficiary of an expanded U.S. military aid program when Washington approved in March 1970 contributions of approximately $\$ 15$ million U.S. dollars per year - an increase of $\$ 10$ million from the original budget (Kissinger memo for Secretary of State and Secretary of Defense, 1970). Jakarta was hoping for yet more and that the Americans would not depart any earlier than 1973 and would leave no security vacuum. Suharto sent General Sumitro to Washington in July 1970 to ask for more military aid, and during discussions with Nixon's National Security Adviser, Henry Kissinger, he stressed that Indonesia was not yet a 'real power' and was still unable to take over the responsibility of security in Southeast Asia. Furthermore, the Indonesian Government had not intended to expand its armed forces before 1973, instead deciding to concentrate on economic development and 'sacrifice' security for the sake of national reconstruction. Jakarta was worried that its neighbors - Thailand, Singapore, Philippines, and Malaysia lacked the military power to withstand potential internal instability, or stand up to intensive Soviet diplomacy. Besides, these Asian nations might turn to the Soviet side to counter Chinese infiltration. Therefore, Indonesia now had to develop strong armed forces and hoped to acquire military supplies from Western Europe and the U.S. (Memo of Conversation between Sumitro and Kissinger, 1970). Kissinger responded very positively to Sumitro, stating that, 'we recognized the Indonesian role, precisely what the Nixon Doctrine required (Memorandum of Conversation between Sumitro and Kissinger, 1970).

Although the Americans did not presume that Indonesia's request for more arms was out of regional altruism, Jakarta was extremely keen to secure funds for six C130 planes, and an M-16 rifle factory and American officials noted that they might have used their support for and participation in regional cooperation as part of their bid. NSC staff member, John H. Holdridge raised that possibility with Henry Kissinger, before adding that while there was still no movement towards a regional security arrangement in Southeast Asia, 'the Indonesians might just be able to get things going' (Memorandum, John H. Holdridge to Kissinger, 1970). Nixon authorized an increase in military aid to Indonesia to $\$ 18$ million for the 1971 fiscal year (Memorandum, Holdridge and Kennedy to Kissinger, 1970).

The Australian Government was also hopeful that Jakarta would pursue a greater interest in a collective security for Southeast Asia, despite Suharto's preoccupation with the economy and internal disputes along with the continuation of the Indonesian position of non-alignment. Malik's efforts to arrange an international conference in Jakarta in 1970 on how to bring peace to Cambodia was the cause of these high hopes in Canberra. The officials believed that the Jakarta Conference on Cambodia revealed the Indonesian Government's willingness to take a leading role in regional security (NIC 1(70), 1970).

Britain as well recognized the importance of Indonesia as an emerging leader in Southeast Asia. In 1971, the British Ambassador in Jakarta urged the British Government to acknowledge the growing importance of Indonesia to regional stability. He wrote to the Foreign Office that the longterm security of British investments in Malaysia and Singapore depended on the 
fortunes of Indonesia and hoped that London would steadily increase its aid program there. Ambassador Combs felt that the Indonesians viewed their position in Southeast Asia, as resident guarantors of stability in the region, were keen supporters of ASEAN and were increasingly likely to take the lead on regional policies (Combs, to Foreign Office, 1971). In early 1969, London was providing $£ 200$ million a year on aid and technical assistance to the Far East. While this support was mostly bilateral, the British placed a lot of emphasis on multilateral aid to Southeast Asia and the opportunities it presented for regional cooperation. In doing so had played a role in many regional bodies such as the Colombo Plan, the ADB, the Mekong Committee, and the specialized institutions of the UN (Speech, Maclehosesp, 1969).

\section{The Zone of Peace, Freedom and Neutrality}

As the level of American and British military involvement in Southeast Asia declined, the five ASEAN countries started to pay closer attention to political and security issues. However, each of these nations had different security arrangements. Thailand and the Philippines were members of the Southeast Asia Treaty Organization (SEATO), and the Philippines had a security treaty with the U.S., Malaysia, and Singapore were members of the FPDA. Indonesia had no security deals but shared joint-military arrangements with Malaysia. Nevertheless, there was a new attitude towards a reassessment of past policies and practices in an aim to seek more regional independence. As a result, ideas of some neutral area presented as a solution to the changed security environment in Southeast Asia. The Malaysians proposed a neutralization concept, while the Indonesians, Thai, Filipinos, and Singaporeans showed their preference for a zone of peace, freedom and neutrality (NIC 124(72), 1972).

These proposals first discussed at a meeting of ASEAN foreign ministers in Kuala Lumpur in November 1971. At this venue, the Malaysians sought an agreement that all foreign powers should be excluded from Southeast Asia, that the region should not use as a theatre for international power struggles, and that the great powers - the U.S., Soviet Union, and China - would guarantee this. This proposal was unacceptable to the four other representatives at the meeting. They did not want to see a certain reference to 'neutralization' or great power guarantees. The meeting's declaration reflected this. In the end, the meeting stated that the ASEAN nations would make all necessary efforts to enable Southeast Asia to be recognized as a zone of peace, freedom, and neutrality that was free from any form of interference by outside powers. The regional nations would also make every effort to increase cooperation amongst themselves (Canberra to Australian posts, 1972).

However, each member state had different aspirations regarding security in Southeast Asia and their existing bilateral relationships. For the Malaysians, ZOPFN was a means to achieve domestic security without cooperative arrangements with nonregional or regional states (NIC 303(74), 1974). For the other four ASEAN nations, external security guarantees still viewed as necessary. Thailand and the Philippines continued to place importance on the U.S. as their main protecting power. Singapore, with an economy oriented to manufacturing and exporting, on the other, hand believed 
its interests were best served by an opendoor policy for all the great powers, and not only one powerful ally. Indonesia saw itself as playing an independent role in the region, which involved encouraging its neighbors to strengthen their security systems as well as practice closer regional cooperation. At the same time, Jakarta also placed a lot of reliance on its relationship with the U.S. for both economic assistance and a guarantee of regional security (NIC 124(72), First Draft, 1972).

By 1973, ZOPFAN continued to exist as a mere statement of intent rather than any concrete framework. Indonesia, especially, was in no hurry to see the implementation of the neutralization proposal because of its wish for a continued U.S. military presence (Memo, Kissinger to Ford, 1975). Singapore also supported American military presence in the region and during a visit to the U.S. in March 1973, Lee Kuan Yew emphasized the benefits to achieving the long-term objective of a quadripartite balance between U.S., Soviet Union, Japan and Western naval forces. In turn, the neutralization concept did not appear to be a factor severely affected by the U.S. military planning in the region, nor did it halt the flow of American economic and military assistance (NIC 57(73), 1973). Indeed, ZOPFAN reflected the changes taking place in Southeast Asia that the ASEAN nations were unable to influence, as they were unable to agree on what would be the future role of the external powers (Narine, 1998, pp. 198-201). Towards the end of the decade, the Malaysians had lost interest in the concept, as had the other ASEAN member states (Response to Proposed Parliamentary Question, 1977).

\section{Diversification}

Despite the signings of ZOPFAN, and an agreement in 1973 to establish a Permanent ASEAN Secretariat in Jakarta, Washington felt pressure from within Southeast Asia. Notably, Thailand and the Philippines, retain SEATO as a symbol of American presence in the region during its transitional period of disengagement (Buszynsky, 1981, pp. 287-296). However, Bangkok and Manila did agree to abandon the military component of SEATO in response to Australian and New Zealand pressure on Washington to downgrade the alliance as a price of their continued membership.

The issue of a changing role for SEATO raised during a meeting with Nixon and the SEATO General Secretary, General Sunthorn, just days before the September 1973 SEATO Council meeting. During the former, when Sunthorn suggested that SEATO could play a future role in supplementing bilateral aid programs in Asia, Nixon replied, 'that can give meaning to the organization. The military is very important, but this is also helpful' (Memo of conversation, President Nixon and General Sunthorn, 1973). At the $18^{\text {th }}$ SEATO Council meeting of 28 September 1973, all delegates agreed to abolish the military structure of SEATO, except military exercises.

Canberra's pressure to downgrade SEATO reflected the regional policy aims of the Australian Prime Minister, Gough Whitlam. When he first came to office in 1972, Whitlam endorsed proposals for neutralization of the Indian Ocean and Southeast Asia, sought to withdraw Australian forces from Vietnam, praised the Guam Doctrine and Nixon's moves towards détente with China and the Soviet Union, and showed little support for the FPDA or 
SEATO. For Whitlam, supporting regional cooperation would be one of the main elements of Australia's foreign policy for the 1970s with less emphasis on military pacts (Briefing Paper, 1974). This increased emphasis on regionalism and cooperation between the superpowers led to calls from Whitlam to propose an Asian and Pacific organization that would eventually include China's membership. The idea would be to bring the Asia-Pacific nations closer without the interference of the major powers (The Hobart Mercury, 1973). Such an organization was not supposed to replace SEATO, ASPAC or ASEAN, nor was it to transform these organizations. Rather, Whitlam attempted to propose new ideas about regional cooperation (Letter, Paris to Canberra, 1973).

The Singaporeans also had visions of other regional groupings. Rajaratnam told his Australian counterpart during a meeting in Canberra in November 1973 that while a long-term objective for his government was a larger regional group, this would come about with the assistance of the formation of some smaller sub-regional groupings. Suggestions for these sub-groups were the possibility of a smaller organization made of up of Indonesia, Australia, New Zealand and Papua New Guinea, and creating a group for the four Commonwealth countries in the region. These groups would run alongside ASEAN and the FPDA, strengthening Southeast Asian unity (Record of Conversation, Rajaratnam and Willesee, 1973).

\section{The End of the War in Vietnam}

The end of the war in Vietnam and the withdrawal of American forces paved the way to closer cooperation between some
Southeast Asian nations. During the 1975 Foreign Ministers' Meeting, the discussion was dominated by the implication of the political changes in Indochina. Ministers expressed optimism and caution and concluded that the war's end provided hope for securing peace, progress, and stability in Southeast Asia and decided to initiate friendly relations with the Indochina nations (Draft Paper, 1975).

At the first meeting of Heads of ASEAN governments in Bali in February 1976, members reiterated the commitment to the organization and at a subsequent meeting of economic ministers; the agreement reached on the establishment of an industry in each member country where there would be joint equity participation that would be developed to benefit the region. The Philippines then suggested the establishment of an ASEAN common market; however, this proposal was only supported by Singapore. Instead, discussions commenced on whether to set up a system of preferential tariffs. By the mid-1970s, ASEAN members had also started cooperating closely in international bodies, coordinating votes at the $\mathrm{UN}$ and representations to the European Economic Community (EEC) on economic matters (Response to Proposed Parliamentary Question, 1977). Significantly, member states obtained from the EEC recognition of ASEAN as one region and preferential access to certain commodities into EEC markets, strengthening relations between the two regional blocs (Jakarta to Canberra, 1974). ASEAN also pursued external economic support from wider regional states, security some joint economic cooperation projects with Australia, and seeking similar cooperation with New Zealand and Canada. 
Japan also started expressing a willingness to undertake joint economic ventures with the regional group, despite earlier refusals to do so (Jakarta to Canberra, 1974).

Despite closer cooperation economically and diplomatically, ASEAN member states continued, ten years after the association's inauguration, to differ as for whether ASEAN should pursue security objectives. Indonesia was one of the stronger supporters of security cooperation amongst members, but even Jakarta was concerned about the organization presenting an image of a defensive alliance. Thus, most military cooperation in the region remained bilateral and at the 1976 ASEAN summit in Bali, leaders agreed to continue to cooperate on security matters, on a non-ASEAN basis (Memo, U.S. Interests, and Objectives in the Asia-Pacific Region, 1976).

Independence and non-alignment were a major goal for ASEAN members regarding security cooperation; however, relations with Vietnam also shaped defense issues, as there was a consensus among the member's states not to confirm Vietnamese suspicions that ASEAN would become the next SEATO. Hanoi's position was that while it was prepared to develop bilateral relations with ASEAN member states, it was not willing to deal with ASEAN as an Association. In turn, the Southeast Asian member nations in ASEAN, despite increased cooperation within the organization as well as continued aspirations for independence and nonalignment, sought continuing American involvement in their region as a deterrent to the Soviet Union and Chinese strategic ambitions as well as Japanese economic domination (FCO paper, 1977).
After the second summit meeting of ASEAN heads of Government in Kuala Lumpur on 1977, ASEAN leaders maintained the level of cooperation in economic areas and took steps to increase cooperation in cultural and social fields. One of the most substantial areas of progress was in ASEAN's external relations through discussions with the Prime Ministers of Australia, Japan and New Zealand on common foreign policy and especially foreign economic policy. As Lee Kuan Yew pointed out in his closing statement at the meeting, 'it is psychologically easier to deal with ASEAN's external partners than to sort out intra-regional arrangements between the partners themselves.' These arrangements are an indication that ASEAN nations would continue to value both cooperation within the Association while maintaining their external relationships (ASEAN Information Paper, 1977).

\section{Conclusion}

Policy objectives from inside the countries and outside of Southeast Asia towards regional cooperation and security had been developing since the end of the Second World War. Economic development viewed as essential for containing communist influence and preventing internal insurgencies in the region. Regional cooperation was one way of providing financial assistance to newly independent nations without the appearance of foreign interference in regional affairs. The aim for many of the countries involved in Southeast Asian regionalism was that growth and prosperity would come through regional development programs with external support. This program would then expand to some form of collective security led by the Southeast Asian nations themselves. This 
policy started to gather pace during the 1950s and 1960s. By the late 1950s, the U.S. administration was strongly promoting the UN Economic Commission for Asia and the Far East as one of the most important multilateral groupings in promoting regional economic and social cooperation and development. In 1950, the U.S. supported the development of the Mekong Basin as a long-range project to secure regional cooperation between Burma, Cambodia, Laos, Thailand, and Vietnam. In the early 1960s, the U.S. tried to promote regional cooperation in Asia by urging closer Japanese relations with other countries in the region, initially through the Association of Southeast Asia. Key to this plan was the role that the regional nations would play themselves. For Western countries, regional cooperation not only potentially provided a vehicle for containing communism in Asia, but the policy presented an alternative security system in replace of Western military bases. Southeast Asian nations themselves supported closer regional integration as a means of containing Chinese communist influences and for countering the decline of Western military support. The inauguration of ASEAN paved the way for a formal regional association to bring some Southeast Asian nations together, and although the organization's initial aim was claimed to be socioeconomic collaboration, political factors such as the promotion of regional peace and stability were present from the beginning. Therefore, while formal regional cooperation came directly out of initiatives from Southeast Asian leaders, it did not end continued Western financial support to local institutions, nor did it end external bilateral security relationships. In the early years of ASEAN, Asian initiatives towards economic development and security relations continued to be supported by foreign powers.

\section{About Author}

Dr. Sue Thompson is a Senior Lecturer at the National Security College in the Crawford School of Public Policy at the Australian National University. Her focus of research examines the history of regional cooperation in Southeast Asia during the Cold War with a focus on foreign power influences in the post-war evolution of Southeast Asian regionalism. Dr. Thompson has conducted extensive fieldwork in North America, Europe, and Southeast Asia and is currently working on her second soleauthored book on this topic. Dr Thompson completed her Ph.D. from the School of Oriental and African Studies (SOAS) at the University of London in the United Kingdom. She holds a Master's degree from the London School of Economics and a Bachelor degree with honours from the Australian National University.

\section{References}

\section{Primary Source Archival Material}

Letter, H.V. Evatt to Nelson T. Johnson, 24 February 1944, A989, 44/735/168/20, NAA \& Cablegram, Bruce to Curtin, 10 November 1944, A989,44/630/5/1/11/22, National Archives of Australia (NAA).

Memorandum, for Butterworth and Fisher, 15 July 1949, Box 5, John F. Melby Papers, China File, Publications, General, Box 5, Harry S. Truman Library (HSTL).

Memorandum, Secretary of State and Butterworth, 16 January 1950, John F. 
Melby Papers, China File, Publications, General, Box 5, HSTL.

Memorandum, Landon to Rostow, 6 March 1961, National Security Files, Countries, Laos General, Box 130, John F. Kennedy Library (JFKL).

Minute, A.J. de la Mare to Mr. Samuel, 23 January 1967, FCO 15/18 and Foreign Office Memorandum, July 1966, FO 371/187566, The National Archives (United Kingdom) (TNA).

Administrative History of the Department of State during the Administration of President Lyndon B. Johnson, November 1963-January 1969, Volume I, Administrative History, Department of State, Volume I, Chapters 7-9, Box 3, Lyndon Baines Johnson Library (LBJL).

Conversation between Ball and Talbot, 22 February 1965, Papers of George W. Ball, Indonesia, National Security File, Box, 4, LBJL.

Talking Points for Bundy from Chester L. Cooper on A Regional Development Proposal for Southeast Asia, National Security File, Country File Vietnam, Box 54, LBJL.

Rusk to Rev. Henry Van Dusen, 10 September 1965, Central Policy Files 1964-66, Political Affairs and Relations, RG 59, Box 1897, National Archives at College Park (NARA).

Washington to Singapore, 23 November 1965, Box 1803, Central Policy Files 1964-66, Political Affairs and Relations, RG 59, Box 1803, NARA.

Memorandum for Rostow from William J.
Jorden on Elements of Progress in Asia, 24 June 1966, National Security File, Name File, Box 5, LBJL.

Memorandum from Ropa to Rostow, 11 April 1966, National Security File, Name File, Box 7, LBJL.

Administrative History of the Department of State during the Administration of President Lyndon B. Johnson, November 1963-January 1969, Volume I, Administrative History, Department of State, Volume I, Chapters 7-9, Box 3, LBJL.

British Embassy in Washington Aide Memoire on The Western Position in South East Asia, 13 February 1964, National Security File, Country File, Vietnam, Box 53, LBJL.

Record of discussion between Rusk and Stewart, 14 May 1965, FO 371/180439, TNA.

Kuala Lumpur to Ottawa, 22 February 1966, FCO 15/18, TNA.

Memorandum, N. Pritchard to Lord Beswick, 20 May 1966, FO 371/187564, TNA.

London to certain missions, 26 May 1966, FO 371/187564, TNA.

Ropa to Rostow, 28 July 1966, Name File, Ropa Memos, National Security File, Box 7, LBJL.

Kuala Lumpur to London, 3 June 1966, FO 371/187565, TNA.

Jakarta to Washington, 27 May 1966, Foreign Relations of the U.S. (FRUS) 1964-68, p. 432. 
Record of meeting between Colin Jackson MP, Tam Dalyell MP and General Suharto, 2 June 1966, PREM 13/1058, TNA.

Kuala Lumpur to Washington, 3 June 1966, Central Policy Files 1964-66, Political Affairs and Relations, RG 59, Box 2452, NARA.

Kuala Lumpur to Canberra, 30 May 1966, A1209, 1964/67/15, NAA.

Kuala Lumpur to Washington, 13 June 1966, Central Policy Files 1964-66, Political Affairs and Relations, RG 59, Box 2452, NARA.

Washington to Kuala Lumpur, 12 October 1966, Central Files 1964-66, Political Affairs and Relations, RG 59, Box 2453, NARA.

Vice-president to Johnson, 5 January 1966, Name File - Vice-president Volume I, National Security File, Box 4, LBJL.

Record of conversation between Rusk and Thanat Khoman, 28 June 1966, Central Policy Files 1964-66, Political Affairs and Relations, RG 59, Box 1898, NARA.

Jakarta to Canberra, 3 March 1967, A4359/14, 221/5/22 part 1 , NAA.

National Intelligence Committee (NIC) 303(74), First Draft, 5 July 1974, A1838, 3004/13/21 part 28, NAA.

Washington to Canberra, 17 August 1967, A9564, 221/4/16, NAA.

Kuala Lumpur to Canberra, 26 May 1967, A1838, 3004/13/21 part 1, NAA.

Washington to Canberra, 17 August 1967,
A9564, 221/4/16, NAA.

Canberra to all posts, 5 September 1967, A1838, 3004/13/21 Part 3, NAA.

Washington to Canberra, 17 August 1967, A9564, 221/4/16, NAA.

Canberra to certain posts, 9 August 1967, A9564, 221/4/16, NAA.

Canberra to all posts, 5 September 1967, A9564, 221/4/16, NAA.

Talking points for meeting with Malik, by Kissinger, 24 September 1974, National Security Adviser, Presidential Country Files for Asia and the Pacific, Indonesia, Box 6, Gerald R. Ford Library (GRFL).

Kuala Lumpur to Canberra, 17 December 1969, A9564, 221/4/16, NAA.

Record of meeting between Wilson and Nixon, 3 August 1969, PREM 13/3027, TNA.

President Richard Nixon Statement on the Asian Development Bank, Philippines, 27 July 1969, Melvin R. Laird Papers, 1953-2004, Department of Defense Papers; Baroody Subject File, SALT, 1968-1972, Box A90, GRFL.

William P. Rogers speech before the national Press Club, Canberra, 8 August 1969, Melvin R. Laird Papers, Department of Defense Papers: Baroody Subject File, SALT, 1968-192, Box A90, GRFL.

White House Press Statement, 25 February 1970, NSC Files, Subject Files, Asia Development Bank, Box 308, Nixon Presidential Library (NPL). 
Singapore to Washington, 14 November 1969, Central Policy Files 1967-69, Defense, RG 59, Box 1518, NARA.

Memorandum, Kissinger to Agnew, December 1969, NSC Files, Henry A. Kissinger Office Files, Country Files Far East, Box 82, NPL.

Memorandum, East Asia and the Pacific, Background on Regional Cooperation, 8 December 1969, NSC Files, Henry A. Kissinger Office Files, Country Files - Far East, Box 82, NPL.

Manila to Canberra, 2 January 1970, A5882/CO818, NAA.

Bangkok to Canberra, 18 November 1969, A1838, CO67/1/4/41 Part 1, NAA.

NIC Note 4/70, 14 October 1970, A1838 3001/1/7/ Part 1, NAA.

National Security Decision Memorandum 126, 11 August 1971, National Security Adviser, NSC East Asian and Pacific Affairs Staff Files, (1969) 1973-1976, Subject File: Kissinger Memcons (5), Box 15, GRFL.

Kuala Lumpur to Canberra, 2 January 1970, A5882/CO818, NAA.

Singapore to Canberra, 3 January 1970, A5882/CO818, NAA.

Jakarta, Kuala Lumpur, Singapore to Canberra, 2 January 1970, A5882, CO818, NAA.

Kissinger memorandum for the Secretary of State and Secretary of Defense, 11 March 1970, Kissinger-Scowcroft West Wing Office Files, 1969-1977, General Subject File: Indonesia, Box

\section{4, GRFL.}

Memorandum of Conversation between Sumitro and Kissinger, 1 July 1970, Kissinger-Scowcroft West Wing Office Files, 1969-1977, General Subject File: Indonesia, Box 14, GRFL.

Memorandum of Conversation between Sumitro and Kissinger, 8 July 1970, Kissinger-Scowcroft West Wing Office Files, 1969-1977, General Subject File: Indonesia, Box 14, GRFL.

Memorandum, John $\mathrm{H}$. Holdridge to Kissinger, 13 October 1970, Kissinger-Scowcroft West Wing Office Files, 1969-1977, General Subject File: Indonesia, Box 14, GRFL.

Memorandum, John H. Holdridge and Richard T. Kennedy to Kissinger, 18 November 1970, Kissinger-Scowcroft West Wing Office Files, 1969-1977, General Subject File: Indonesia, Box 14, GRFL.

NIC 1(70), 9 September 1970, A452, 1970/4122, NAA.

W.I. Combs, British Ambassador to Indonesia to Foreign Office, 15 November 1971, FCO 24/1019, TNA.

Speech by British Ambassador Mr. C.M. Maclehose to Lions Club of Saigon, 24 February 1969, A1838, 67/1/4/41 Part 1, NAA.

NIC 124(72), 4 August 1972, A1838, 683/72/124, NAA.

Canberra to Australian posts, 29 August 1972, A1838, 67/1/4/41 Part 2, NAA.

NIC 303(74), 2 September 1974, A1838, 
3004/13/21 Part 28, NAA.

NIC 124(72), First Draft, 25 July 1972, A1838, $683 / 72 / 125$, NAA.

Memorandum, Kissinger to Ford, 1 July 1975, Box 11, National Security Adviser Presidential Briefings Material for VIP visits, 1974-1976, GRFL.

NIC 57(73), September 1973, A1838, $683 / 72 / 57$, NAA.

Response to Proposed Parliamentary Question on ASEAN by A.M. Simons, South-East Asia Department, 17 January 1977, FCO 15/2249, TNA.

Memorandum of conversation between President Nixon and General Sunthorn, SEATO Secretary General, 21 September 1973, FRUS, 1969-76, Vol. E-12, Documents on East and Southeast Asia, 1973-76, Washington, 2011.

Department of State Briefing Paper, Januar 1974, Box 65, Ford Vice-Presidential Papers, Office of Assistant for Defense and International Affairs Files, 1973-1974, John O. Marsh, GRFL.

Letter, Paris to Canberra, 11 September 1973, A1838, 683/72/57, NAA.

Record of Conversation, S. Rajaratnam and Don Willesee, 15 November 1973, A9564, 221/4/16, NAA.

Draft Department of Foreign Affairs Paper on ASEAN, 16 December 1975, A9564, 221/4/16, NAA.
Response to Proposed Parliamentary Question on ASEAN by A.M. Simons, South-East Asia Department, 17 January 1977, FCO 15/2249, TNA.

Jakarta to Canberra, 9 May 1974, A9564, 221/4/16, NAA.

Draft Department of Foreign Affairs Paper on ASEAN, 16 December 1975, A9564, 221/4/16, NAA.

Memorandum, Scowcroft to Secretary of State, Secretary of Defense, Director of Central Intelligence, U.S. Interests and Objectives in the Asia-Pacific Region - Part 1, NSSM 235, 5 November 1976, NSC Institutional Files, NSSM 231, Box 39, GRFL.

FCO paper on British Policy Towards the Countries of ASEAN, July 1977, FCO $15 / 2249$, TNA.

Interdepartmental Committee on ASEAN, Information Paper, 9 September 1977, FCO 15/2247, TNA.

Books, Book Sections, Journal Articles, and Newspapers

Acharya, A. (2012). The making of Southeast Asia: International relations of a region. Singapore: ISEAS.

Anwar, D. F (1994). Indonesia in ASEAN: Foreign policy and regionalism. Singapore: ISEAS.

Buszynsky, L. (1981). SEATO: Why it survived until 1977 and why it was abolished. Journal of Southeast Asian Studies, 12(2), 287-296.

Gill, R. (1997) ASEAN towards the $21^{\text {st }}$ century: 
A thirty-year review of the Association of Southeast Asian Nations. London: ASEAN Academic Press.

Lee Kuan Yew, (2000). From Third World to First: The Singapore Story: 1965-2000. Singapore: Singapore Press Holdings.

Mitcham, C (2012). Australia and development cooperation at the United Nations: Towards poverty reduction. In J. Cotton \& D. Lee (eds.), Australia and the United Nations. Canberra: Commonwealth of Australia.

Narine, S. (1998). ASEAN and the management of regional security. Pacific Affairs, 71(2), 198-201.

Tarling, N, (2006). Regionalism in Southeast Asia: To foster the political will. London: Routledge.

The Hobart Mercury, 22 February 1973. 